\title{
Conversa com o editor
}

Já que a maior parte dos textos publicados nesta edição de Correlatio foi incluída no Dossiê, apresentarei aqui apenas os dois artigos da seção livre, uma entrevista e uma comunicação.

O primeiro artigo: "Mito" e "Poesia" a partir de Tillich e Heidegger,

busca apresentar a interface "mito" e "Poesia" em sua relação fundamental com a situação humana, a partir do pensamento de Paul Tillich e Martin Heidegger. Para tanto, propõe-se um diálogo entre a teologia da cultura de Tillich (1886-1965) e a filosofia de Heidegger (1889-1976). Nesse sentido, a autora, Danjone Regina Meire, se volta, especialmente, para as obras "Teologia Sistemática" (1951-63), "Dinâmica da Fé" (1957) e "Teologia da cultura" (1959) de Tillich. Assim como, para as obras "Ser e Tempo" (1927), "Hölderlin e a essência da poesia" (1936), "A coisa" (1950), "Poeticamente o homem habita" (1951) e "O que significa pensar? (1951-1952) de Heidegger. A autora instaura aqui, uma análise do problema da existência humana e sua relação primordial com a questão da linguagem. Nessa perspectiva, se destacam a interface mito, religião e linguagem na ontologia de Tillich. Bem como, se enfatizam a relação mito, "Poesia" e existência no pensamento de Heidegger. Assim, as questões da existência e da linguagem são relevantes tanto para a ontologia de Tillich quanto para a ontologia de Heidegger.

O artigo Saturnais: Culto, Religião e Simbolismo, inscreve-se no perfil da nossa revista pelas relações estabelecidas entre religião e cultura. Helena Raquel de França Costa e Altierez Sebastião dos Santos apresentam uma abordagem dos aspectos religiosos, simbólicos e cúlticos presentes no festival romano das Saturnais. Foi destacada a estru- 
tura social e religiosa da Roma antiga, a mitologia em torno do deus Saturno e a festa a ele dedicada. A pesquisa bibliográfica privilegiou a obra do escritor romano Macróbio, do século IV. Destaca-se a continuidade cultural entre antiguidade e contemporaneidade nas dimensões do sagrado e do festivo.

Por sua vez, Edimar Brígido relata uma entrevista realizada com Annette Dumoulin, que vive em Juazeiro do Norte há várias décadas e se especializou nos estudos a respeito do Padre Cícero Romão Batista, da sua condenação e da sua atual reabilitação, que pode até levar a uma beatificação pela igreja católica. Conforme o autor, "é preciso revolver a terra seca do Sertão do Cariri para descobrir as marcas deixadas pelo julgamento que culminou na condenação do padre mais popular do nordeste brasileiro. Entre defesas e acusações, Juazeiro se tornou território da disputa dialógica e jurídica, conquistando importância, não somente religiosa, mas também política. O chão deste ambiente é sagrado, uma vez que foi regado com o suor de milhares de homens e de mulheres, que tornaram-se romeiros, peregrinos deserdados da sorte, desprovidos de amparo, em busca de solução para seus conflitos".

Enfim, colocamos na seção "Comunicações" um breve ensaio, que lembra alguns momentos da implantação do protestantismo no Brasil e do seu impacto sobre as culturas locais. Trata-se de Apontamentos sobre a implantação do protestantismo no Brasil: história, cultura e tradição. Deixo aqui falar o autor, Fernando Ripoli, no resumo do texto: "O protestantismo no Brasil tem sido um campo de estudo por muitos pesquisadores, sejam eles(as), historiadores, sociólogos, filósofos, antropólogos e cientistas da religião. Nosso objetivo neste pequeno ensaio é repaginar alguns apontamentos sobre o protestantismo no Brasil. Em primeiro lugar, traremos uma definição de protestantismo. Em seguida, apresentaremos as tentativas de implantação dos protestantes em solo tupiniquim, abordando sua militância missionária. Por fim, trabalharemos com os registros dos dias atuais sobre este período para fazer uma leitura do protestantismo de imigração e missão na América Latina."

Desejo a todas e a todos uma ótima leitura! Mas não deixem de considerar o dossiê sobre política e religião. 